\title{
Optimization on $\mathrm{Na}$ and $\mathrm{Ca}$ bentonite activation using response surface method for increasing selectivity of stevioside in stevia extract
}

\author{
Optimasi aktivasi bentonit Na dan Ca menggunakan metode respons permukaan untuk meningkatkan \\ selektivitas steviosida pada ekstrak stevia
}

Ayu Rahayu SARASWATI, Erliza NOOR*) \& Titi Candra SUNARTI

Agro-industrial Engineering Department, Faculty of Agricultural Technology, IPB University, Jl. Raya Dramaga, Bogor 16680, Jawa Barat

Received 11 July 2021 / Accepted 22 October 2021

\begin{abstract}
Abstrak
Permintaan konsumsi ekstrak stevia sebagai pemanis alternatif yang mengandung steviosida dan nol kalori semakin meningkat. Namun, warna gelap dan kandungan tanin yang tinggi dari ekstrak daun stevia menyebabkan aftertaste yang mengganggu dan mengurangi minat untuk konsumsi. Oleh karena itu, proses pemurnian wajib dilakukan. Beberapa penelitian tentang metode pemurnian menunjukkan pendekatan terbaik dengan adsorpsi menggunakan bentonit. Namun bentonit alam memiliki kapasitas adsorpsi yang terbatas dan selektivitas yang rendah. Aktivasi dengan asam dan suhu tinggi diharapkan dapat meningkatkan kapasitas adsorpsi warna dan selektivitasnya dalam mempertahankan steviosida pada ekstrak. Penelitian ini bertujuan untuk mendapatkan konsentrasi asam dan suhu optimum untuk aktivasi menggunakan rancangan percobaan Response Surface Method (RSM) dan aplikasinya pada pemurnian ekstrak daun stevia. Berdasarkan parameter bilangan metilen biru, konsentrasi $\mathrm{H}_{2} \mathrm{SO}_{4}$ yang paling optimum digunakan untuk aktivasi adalah 0,17 N untuk kedua bentonit alam. Temperatur pemanasan adalah $358^{\circ} \mathrm{C}$ untuk Na-bentonit dan $481{ }^{\circ} \mathrm{C}$ untuk $\mathrm{Ca}$ bentonit. Kapasitas adsorpsi maksimum $\mathrm{Na}$ dan Ca-bentonit teraktivasi masing-masing meningkat dari 15,65 dan 38,23 $\mathrm{mg} \mathrm{g}^{-1}$ menjadi 197,72 dan 169,52 $\mathrm{mg} \mathrm{g}^{-1}$. Adsorben terbaik yang digunakan untuk pemurnian adalah Ca-activated, yang meningkatkan klarifikasi ekstrak hingga 81,37\% pada $655 \mathrm{~nm}$ dan 86,64\% pada $410 \mathrm{~nm}$ dibandingkan dengan bentonit Ca alami. Ini juga mengurangi tanin hingga 97,46\% dan lebih selektif untuk memulihkan konten stevia 50,64\% dalam larutan, yang lebih tinggi dari penelitian lain yang dilaporkan sebelumnya.
\end{abstract}

[Kata kunci: bentonit teraktivasi, kapasitas adsorpsi, ekstrak daun stevia]

\begin{abstract}
The demand for stevia extract consumption as an alternative sweetener that contains stevioside with zero-calorie is increasing. However, dark color and high tannin content from stevia leaf extract causes a disturbing aftertaste and reduces interest in consumption. Therefore, the purification process is a mandatory step to be done. Several studies on purification methods show the best approach by adsorption using bentonite. However, natural bentonite has limited adsorption capacity and low selectivity. An activation with acid and high temperature is expected to increase the adsorption capacity of color and its selectivity on maintaining the stevioside at the extract. This study aimed to obtain the optimum acid concentration and temperature for the activation using the Response Surface Method (RSM) experimental design and its application to the purification of stevia leaf extract. Based on the parameter of methylene blue number, the most optimum concentration of $\mathrm{H}_{2} \mathrm{SO}_{4}$ used for activation was $0.17 \mathrm{~N}$ for both natural bentonite. The heating temperature was $358^{\circ} \mathrm{C}$ for Na-bentonite and $481^{\circ} \mathrm{C}$ for $\mathrm{Ca}$ bentonite. The maximum adsorption capacities of activated $\mathrm{Na}$ and $\mathrm{Ca}$-bentonite were increased from 15.65 and $38.23 \mathrm{mg} \mathrm{g}^{-1}$ to 197.72 and $169.52 \mathrm{mg} \mathrm{g}^{-1}$, respectively. The best adsorbent used for purification is Ca-activated, which increased extract clarification up to $81.37 \%$ at $655 \mathrm{~nm}$ and $86.64 \%$ at $410 \mathrm{~nm}$ compared to natural $\mathrm{Ca}$ bentonite. It also reduced tannin up to $97.46 \%$ and was more selective to recover $50.64 \%$ stevia content in the solution, which was higher than other previously reported studies.
\end{abstract}

[Keywords: activated bentonite, adsorption capacity, stevia leaf extract] 


\section{Introduction}

Stevia rebaudiana leaf extract is a sugar substitute for diabetic type II diet, a healthy and safe sweetener because of its 0 calories (Tiwari, 2010; Lemus et al., 2012). Based on Liquid Chromatography (LC-QTOF/MSMS) analysis by Molina et al. (2017), both polar and non-polar extracts of stevia leaves contain more than 80 components of active ingredients, including terpenoid molecular groups, phenolic groups, quinic acid, caffeic, and their derivatives, sesquiterpenoids, fatty acid, and fatty acid amides. Stevioside and rebaudioside A in stevia leaf extract represent the sweet taste of stevia leaf extract and have a sweetness level of up to 300-450 times that of glucose (Characostas et al., 2008). Stevioside is found in a higher level as 4-15\%, while rebaudioside A is $2-4 \%$ (Raini \& Isnawati, 2011). Based on JECFA regulations (2007), the use of stevia as a sweetener must have steviol glycosides equivalent to $95 \%$. This regulation makes the purification process of stevia leaf extract significant to produce stevia extract with good quality and safe to use as an alternative sweetener to replace sugar.

The purification process of stevia leaf has been studied with several methods such as filtration, adsorption, and membrane separation process. Among these, adsorption is most valuable for purification (Liu et al., 2019). Previous studies using the adsorption method with zeolite $\mathrm{Ca}$ increased solution clarity up to $80 \%$ but left a bitter taste from $\mathrm{Ca}$ dissolved (Morases \& Machado, 2001). An approach on adsorption using activated carbon reduced the tannin content up to $39 \%$, yet it did not calculate the stevioside level at the final product (Kusumaningsih et al., 2015). Research related to optimizing contact time for purification of stevia extract using activated bentonite increased clarification of up to $95 \%$ by 30 minutes (Husada et al., 2018). The weakness of the natural adsorbent used is its low adsorption capacity and selectivity, where the stevioside can be adsorbed at the same time with the color pigment. Therefore, we developed a pretreatment of natural $\mathrm{Na}$ and $\mathrm{Ca}$ bentonite used with activation process to increase adsorption capacity and selectivity on maintaining stevioside in the extract.

The adsorption method for purification can be improved by using specific adsorbents or modifying the adsorbent by activation. Activation of adsorbent by chemical, physical, or mechanical means was used for better efficiency and effectiveness. This research determines two activating methods for natural $\mathrm{Na}$ and $\mathrm{Ca}$ bentonite, using $\mathrm{H}_{2} \mathrm{SO}_{4}$ and high temperature. Acid can increase its active site (Dewi \& Twilana, 2012), make it more hydrophobic, and reduce its adsorption power to water (Kurniasari et al., 2011). According to Kurniasari et al. (2011), high temperatures cause recrystallization of the clay adsorbent to produce better crystals with large pores. These improvements of the active site and pores of bentonite used are expected to bind the most impurities in the form of pigments that have large sizes and contain $\mathrm{Mg}^{2+}$ in chlorophyll ion to bond with the active site formed in the activated bentonite used. This adsorbent would be more selective than adsorbing the steviol glycoside molecules, which is stevioside. These changes can improve the adsorbent capacity and selectivity. This research aimed to get the optimum concentration of $\mathrm{H}_{2} \mathrm{SO}_{4}$ and the temperature used for the activation of $\mathrm{Na}$ and $\mathrm{Ca}$ adsorbents. Activated $\mathrm{Na}$ and $\mathrm{Ca}$ bentonites used to purify the crude stevia extract are expected to improve the clarification and maintain stevioside from the extract.

\section{Materials and Methods}

\section{Materials}

Natural $\mathrm{Na}$ and $\mathrm{Ca}$ bentonites were purchased from PT Clariant. The dried stevia leaves were obtained from Stevia Indonesia under the trade name Stevi-Grow. Sulfuric acid $\left(\mathrm{H}_{2} \mathrm{SO}_{4}\right.$ EMSURE $^{\circledR}$ ), methylene blue (CI. 52015) were purchased from Merck Millipore, stevioside analytical standard ( $\geq 95 \%$ HPLC grade) from Sigma Aldrich, and distilled water was produced from Direct-Q® 8 UV Remote Water Purification System.

\section{Bentonite activation}

The experimental design of bentonite activation was carried out using a Central Composite Design (CCD) with Response Surface Method (RSM) to determine the optimum activation conditions. The factors include sulfuric acid $\left(\mathrm{H}_{2} \mathrm{SO}_{4}\right)$ concentration $(1-5 \quad \mathrm{~N})$ and temperature $\left(400-600^{\circ} \mathrm{C}\right)$, while methylene blue number was used as the response variable. Activation with $\mathrm{H}_{2} \mathrm{SO}_{4}$ refers to Rožić et al. (2010), with the ratio of bentonite: acid is 1:5 (w/v). A furnace was used for temperature conditioning for 3 hours. The activated bentonite was then pulverized to 100 mesh for further analysis.

\section{Data analysis}

In this research, the independent variables considered for the optimization process include the concentration of $\mathrm{H}_{2} \mathrm{SO}_{4}$ in $\mathrm{N}$ (X1) and heating temperature in degree Celsius (X2). Coded factor level used based on literature review shown the best-activated condition for the purification of stevia leaf extract. The experimental data obtained were analyzed its optimum response with methylene blue number determination and calculated by Minitab 11 to get the optimum condition. The optimum activated condition was then applied to $\mathrm{Na}$ and $\mathrm{Ca}$-bentonite, respectively. 


\section{Methylene blue number determination}

The analysis refers to Ramadhani et al. (2015) using a standard series of the curve. The linearity equation of the standard is $y=0.19 x-0.2065$ with a regression of 0.9989 . A small amount of bentonite was weighed and then added with 100 ppm methylene blue standard solution. The sample was allowed to react for $1 \times 24$ hours to obtain maximum adsorption. Measurements were carried out at a maximum $\lambda$ of $664 \mathrm{~nm}$ for the standard and sample solution and then calculated using the linearity equation.

\section{Analysis of bentonite crystal diffraction with $x$-ray} diffraction (XRD)

Bentonite sample with 100 mesh size was analyzed for X-ray diffraction pattern using Rigaku XRD with Bragg-Brentano geometry. XRD measurements take in the range of $2 \theta 10^{\circ}-90^{\circ}$ with Co-K radiation used and operated at $40 \mathrm{kV}$ and $25 \mathrm{~mA}$. Scan Speed used is $5 \% \mathrm{~min}$ with a step width of $0.01 \mathrm{deg}$. Diffractions were processed into a graph using Match 3 software to determine the majority of crystals contained in bentonite and their changes before and after activation.

\section{Clarification measurement}

Crude stevia leaf extract solution was adsorbed according to Husada et al. (2018) using a batch method with activated $\mathrm{Na}$ and Ca-bentonite at a ratio of 1:10 (w/v). Adsorption was carried out in the vial, which was stirred at a speed of $210 \mathrm{rpm}$ for 3 hours. The extract was then separated from bentonite using a centrifuge at $6.000 \mathrm{rpm}$ for 10 minutes. The absorbance of the stevia leaf extract solution before and after the adsorption process was measured by spectrophotometer at a $\lambda$ of $665 \mathrm{~nm}$ (for green pigment) and $410 \mathrm{~nm}$ (for yellow pigment) to obtain an increase in clarity value. The clarification of supernatant was analyzed with UV-VIS Spectrophotometer.

\section{Tannin content analysis with folin-denis}

The analysis followed the method of Kharismawati et al. (2009). The liquid sample was mixed with distilled water in a ratio of 1:7. After mixed well, 0.5 part of Folin Denis Reagent Solution was added. This solution was allowed to react completely for 3 minutes. One-part $\mathrm{Na}_{2} \mathrm{CO}_{3}$ was added to the mixture. Incubate the solution in a dark room for 30 minutes before reading it on a spectrophotometer at a wavelength of $745 \mathrm{~nm}$. Tannin concentration $(x)$ calculated by linear regression formula $y=49.1003 x-0.0114$ and a regression of $\mathrm{R}^{2} 0.9951$.

\section{Stevioside analysis with high-performance liquid chromatography (HPLC)}

A modified method by Chaturvedula \& Zamora (2014) was used to analyze the stevioside concentration of stevia crude extract solution by using HPLC. The HPLC used was Waters with UV-VIS detector at the $\lambda 202 \mathrm{~nm}$ and C18 OSD Xbridge ${ }^{\mathrm{TM}}$ column. The method used was a reversephase at $60^{\circ} \mathrm{C}$ with elution buffer Na-Phosphate and acetonitrile (68:32) $\mathrm{pH}$ of 2.63. The standard series was made from $200-1000 \mathrm{ppm}$ of stevioside to verify the method. These standard series should have $\mathrm{R}^{2}$ value between $0.995-1.00$ to be qualified to calculate the stevioside content in the sample.

\section{Results and Discussion}

\section{Bentonite activation}

The activation process was aimed to obtain bentonite with a greater adsorption capacity and a better crystal to clarify the crude stevia leaf extract. Design of experiment using Central Composite Design (CCD) performed with setting the lowest and highest value used. In this research, the lowest $\mathrm{H}_{2} \mathrm{SO}_{4}$ concentration for activating bentonite is $1 \mathrm{~N}$ (Yildiz et al., 2010), while the highest used is $5 \mathrm{~N}$. Meanwhile, the temperature was set from 400$600^{\circ} \mathrm{C}$. From this variable, Minitab 17 generated 13 combinations condition to be analyzed. The combination of experimental design and response can be seen in Table 1 .

The Methylene Blue Number (MBN) is the maximum amount of dye absorbed by $1 \mathrm{~g}$ of adsorbent or color concentration in solids. MBN determines the adsorption capacity of adsorbents in the batch adsorption method (Raposo et al., 2009). This adsorbent is expected to eliminate as much as pigment and tannin in stevia extract. Since pigment and tannin in stevia extract vary widely, we standardized the analytical parameters with methylene blue number.

The MBN response for activated $\mathrm{Na}$ and $\mathrm{Ca}$ bentonite increased compared to natural bentonite. These results align with previous research by Yildiz et al. (2004) and Noyan et al. (2008). However, the addition of $\mathrm{H}_{2} \mathrm{SO}_{4}$ concentration did not always positively correlate with adsorption capacity, as the table showed that higher concentrations have a lower MBN. Mohammad et al. (2020) reported a similar result that low concentrate $\mathrm{H}_{2} \mathrm{SO}_{4}$ produces the highest adsorption capacity. The cations in the dispersed double layer of bentonite are exchangeable with those in the free water. Therefore, methylene blue will exchange cations from both of these sources. To eliminate the free water cations, clay samples must be mixed with sufficient deionized water to dissolve the precipitated salts and cations in the free pore fluid. On these clay edges, the proton surface charge depends on the physico-chemical parameters of the solution ( $\mathrm{pH}$, ionic strength) that control the protonation state. The ion exchange must occur faster between the solution and the basal planes than between the solution and the interlayer flats. 
The optimum condition for activating $\mathrm{Na}$ and Ca-bentonite was calculated using Minitab 17 software. A further test for suitability of the model formed is done by looking at the p-value of lack of fit (Table 2). This further test shows a not significant result in lack of fit and a significant result for the model used ( $p$ value >0.05). Therefore, this optimization model is acceptable for optimization of the bentonite $\mathrm{Na}$ and $\mathrm{Ca}$ activation conditions.

The optimum condition of $\mathrm{H}_{2} \mathrm{SO}_{4}$ concentration for activating $\mathrm{Na}$ and $\mathrm{Ca}$-bentonite was calculated using Minitab 17 software. The optimum concentration is $0.17 \mathrm{~N}$ for both. While the optimum temperature for activating $\mathrm{Na}$ and $\mathrm{Ca}$ bentonite is $358^{\circ} \mathrm{C}$ and $481^{\circ} \mathrm{C}$, respectively. These results are shown in Figure 1, where $\mathrm{X}$-axis is acid concentration, $\mathrm{Y}$-axis is the parameter calculated as adsorption capacity with MBN value, and $\mathrm{Z}$-axis is for the temperature used. This result is in contrast to Husada et al. (2018), which was used $\mathrm{H}_{2} \mathrm{SO}_{4}$ at $3 \mathrm{~N}$ as a reference to determine 0 points in CCD-RSM experimental design. It is caused by the different sources of bentonite used, so they have other active groups and produce different optimum activation points. The Figure shows an optimum adsorption capacity at a low concentration of $\mathrm{H}_{2} \mathrm{SO}_{4}$. It means the active site of bentonite was already saturated and fully charged with $\mathrm{H}^{+}$from the acid at a low concentration. The temperature effect on adsorption capacity in $\mathrm{Na}$ bentonite significantly decreased along with the increase in temperature.

Optimized activated bentonite was then calculated its adsorption capacity using methylene blue solution. Methylene blue is often used as a reference analysis to identify adsorbent properties' initial identification (Nunes \& Guerreiro, 2011). The comparison data of adsorption capacity on its equilibrium concentration is presented in Figure 2. The optimization process is used to maximize the adsorption capacity from bentonite. The adsorption capacity of activated $\mathrm{Na}$ and Cabentonite reached up to $197.72 \mathrm{mg} \mathrm{g}^{-1}$ and $169.52 \mathrm{mg} \mathrm{g}^{-1}$, respectively. Each of these values is higher than the adsorption capacity of natural bentonite. This escalation proves that the activation process has been successful in increasing the adsorption capacity of natural bentonite.

Table 1. The combination of optimization treatment and the response of methylene blue number Tabel 1. Kombinasi perlakuan optimasi dan respons terhadap nilai metilen biru

\begin{tabular}{ccccc}
\hline & $\mathrm{H}_{2} \mathrm{SO}_{4}$ concentration & Heating temperature \\
Konsentrasi $\mathrm{H}_{2} \mathrm{SO}_{4}$ & $\begin{array}{c}\text { Suhu pemanasan } \\
\left({ }^{\circ} \mathrm{C}\right)\end{array}$ & \multicolumn{2}{c}{$\begin{array}{c}\text { Methylene blue number response }\left(\mathrm{mg}^{-1}\right) \\
\text { Respons nilai metilen biru }\left(\mathrm{mg}^{-1}\right)\end{array}$} \\
\cline { 4 - 5 } & $(\mathrm{N})$ & 500 & Na Bentonite & Ca Bentonite \\
\hline 2 & 0.17 & 358 & 19.32 & 45.64 \\
3 & 3.00 & 600 & 10.77 & 5.42 \\
4 & 1.00 & 600 & 8.58 & 33.75 \\
5 & 5.00 & 400 & 7.47 & 16.78 \\
6 & 1.00 & 500 & 19.52 & 38.17 \\
7 & 3.00 & 500 & 8.67 & 18.42 \\
8 & 3.00 & 500 & 9.81 & 13.31 \\
9 & 3.00 & 641 & 9.57 & 17.41 \\
10 & 3.00 & 400 & 10.57 & 19.54 \\
11 & 5.00 & 500 & 14.56 & 13.39 \\
12 & 3.00 & 500 & 11.66 & 17.15 \\
13 & 5.83 & 500 & 6.07 & 15.11 \\
14 & 3.00 & - & 9.63 & 17.60 \\
\hline
\end{tabular}

Table 2. Optimization of bentonite using Minitab 17

Tabel 2. Optimasi bentonit menggunakan Minitab 17

\begin{tabular}{lcc}
\hline $\begin{array}{l}\text { Parameter } \\
\text { Parameter }\end{array}$ & $\begin{array}{c}\text { Activated Na bentonite } \\
\text { Na bentonit teraktivasi }\end{array}$ & $\begin{array}{c}\text { Activated Ca bentonite } \\
\text { Ca bentonit teraktivasi }\end{array}$ \\
\hline p-value of Lack of fit & 0.100 & 0.401 \\
R-sq & $88.39 \%$ & $93.13 \%$ \\
\hline
\end{tabular}




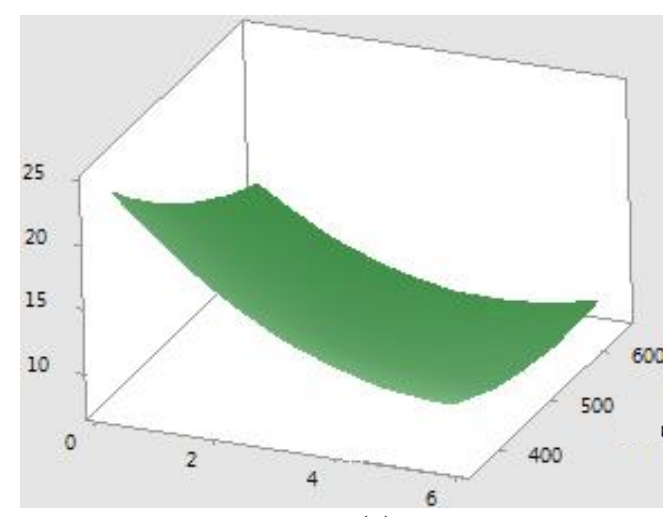

(a)

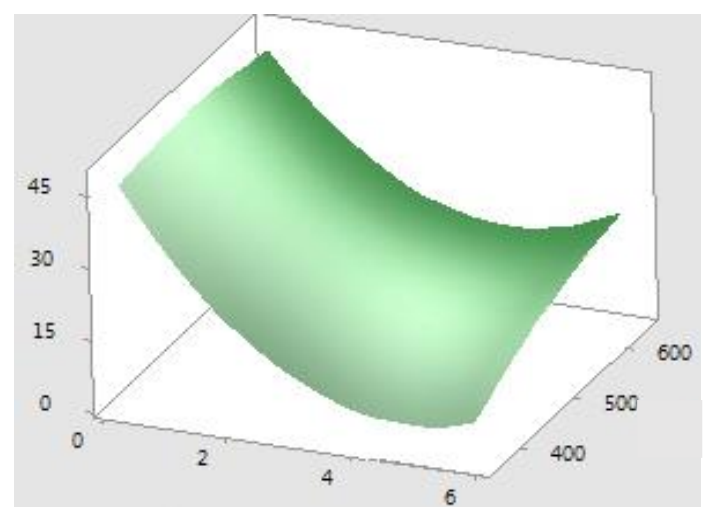

(b)

Figure 1. Optimization curve of adsorption capacity of (a) Na-Bentonite (b) Ca-bentonite Gambar 1. Kurva optimasi kapasitas adsorpsi dari (a) Na bentonit (b) Ca bentonit

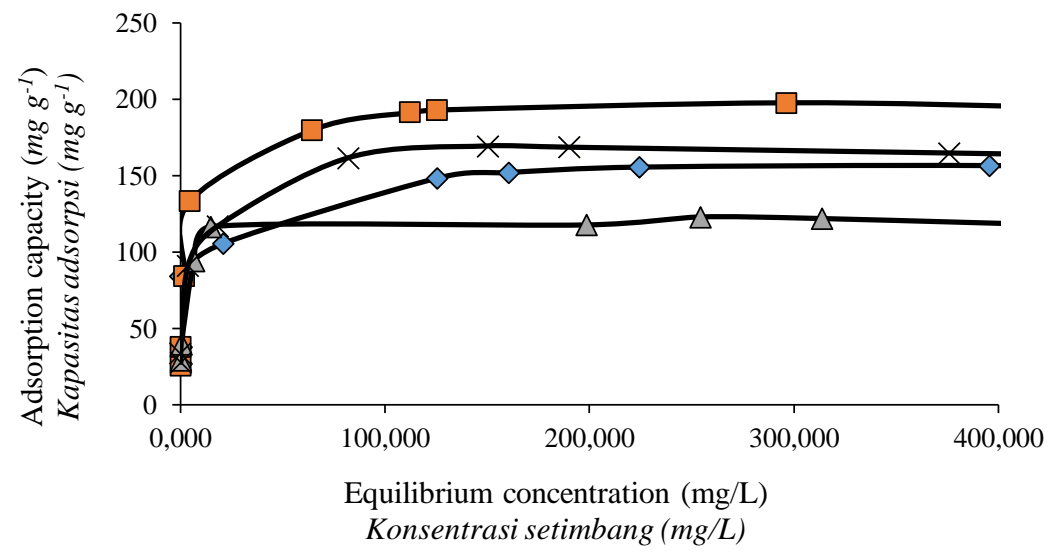

Figure 2. Equilibrium concentration comparison curve of activated and inactivated $\mathrm{Na}$ bentonite and $\mathrm{Ca}$ bentonite $(\longrightarrow$ Na inactivated, $\rightarrow$ Na activated, $\rightarrow$ Ca inactivated, $\rightarrow$ Ca activated)

Gambar 2. Kurva perbandingan konsentrasi setimbang dari Na dan Ca bentonit teraktivasi dan tidak teraktivasi $(\longrightarrow$ Na inactivated, $\square$ Na activated, $\rightarrow$ Ca inactivated, $\rightarrow$ Ca activated $)$

\section{$X$-ray diffraction crystal analysis}

Crystal formed in $\mathrm{Na}$ and $\mathrm{Ca}$ bentonite before and after activation is shown on Figure 3. The peak trend of the $2 \theta$ formed is pointed upwards with a low baseline in $\mathrm{Na}$ bentonite before and after activation. Sharp peaks were also seen in $\mathrm{Ca}$ bentonite before and after activation but tended to have a high baseline. This response did not affect the XRD readings, which were carried out qualitatively. The JCPDS $2 \theta$ value at $20^{\circ}, 35^{\circ}, 55^{\circ}$, and $63^{\circ}$ shown in the graph represents montmorillonite crystal (Ruskandi et al., 2020). Meanwhile, the quartz crystal shows a high dspacing value at $2 \theta 26^{\circ}, 39^{\circ}$ and $42^{\circ}$. So, bentonite used in this research has a composition of montmorillonite and most quartz $\left(\mathrm{SiO}_{2}\right)$.

Based on the diffraction pattern, there is a left shift in $2 \theta$ axis while there is an increment of dvalue (basal spacing), which indicates the formation of an active site due to the activation process. The entry of $\mathrm{H}^{+}$cations from acid between the layers of bentonite minerals replaces the charge balancing cations of the silicate layer in the mineral, causing an expansion of the distance between the existing silicate layers (Mahmudha et $a l ., 2016)$. The increase is expected to absorb more impurities in the leaf extract and be more selective to maintain the stevioside content.

\section{Batch adsorption for stevia leaf extract}

Activated bentonite was then used as an adsorbent for clarification of crude stevia leaf extract. The factor that affects the color of stevia leaf extract is chlorophyll pigment. There are two types of chlorophyll pigment in leaves: chlorophyll A with a dark green color tendency and chlorophyll B with a yellowish-green color (Chaturvedulla \& Prakash, 2011). The chlorophyll pigment in stevia leaves contains $\mathrm{Mg} 2+$ ions, which bind to protein molecules in the plant matrix; during the extraction process by heating, these molecules are denatured 
and unstable to be easily separated and replaced by hydrogen molecules (Arumsari et al., 2019). This process makes a dark color at the extract used in this research. In previous studies (Mahl et al., 2010; Gasamalla et al., 2015), brown color positively correlates to flavonoids, phenols, tannins, and the unpleasant and bitter taste of the extract by separating these compounds.

Figure 4 presents the clarity of stevia extract in quantitative and qualitative. In general, both $\mathrm{Na}$ and Ca-bentonite can adsorb more pigments at lower wavelengths $(410 \mathrm{~nm})$ for yellow pigment. However, the application of activated Ca-bentonite produces higher clarification for stevia leaf extract compared with activated Na-bentonite. These results can be seen from the more amorphous crystals lost in activated Ca-bentonite so that it provides better clarification than activated $\mathrm{Na}-$ bentonite.

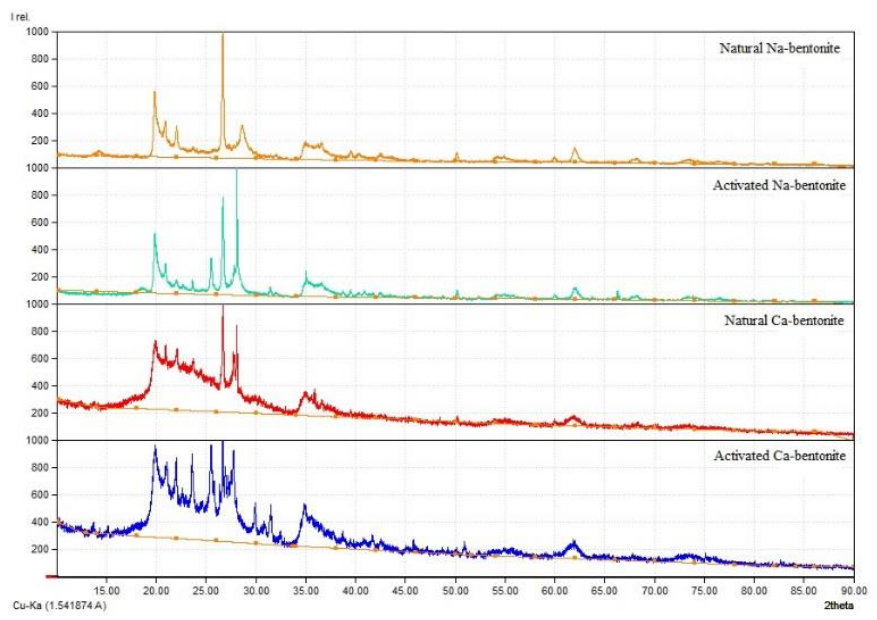

Figure 3. Bentonite diffraction by XRD

Gambar 3. Difraksi bentonit dengan XRD

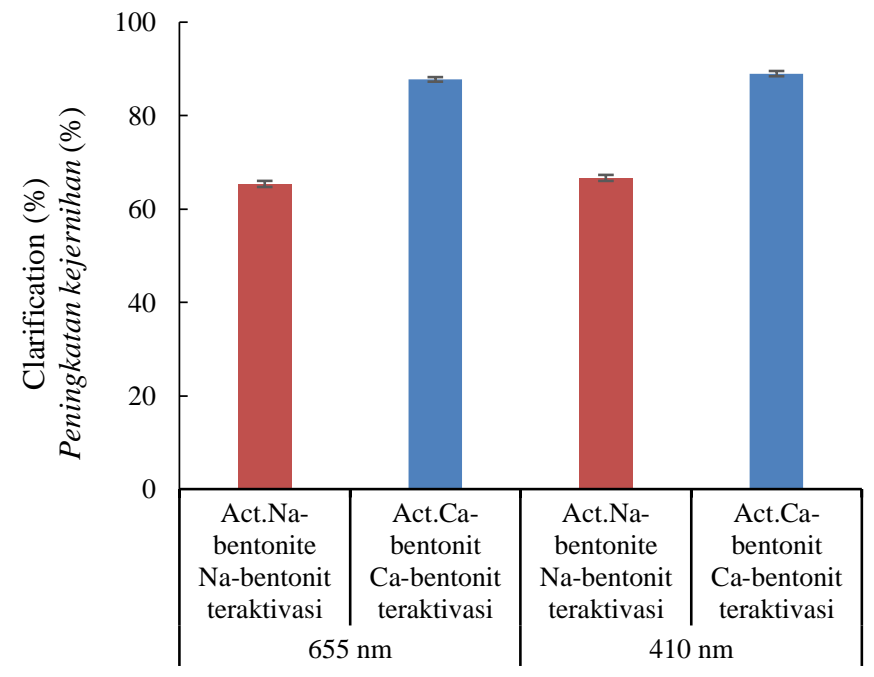

(a)

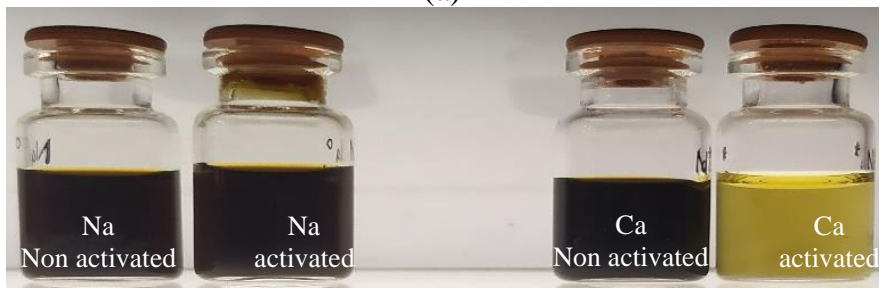

(b)

Figure 4. Stevia leaf extract before and after adsorption process (a) quantitative (b) qualitative Gambar 4. Ekstrak daun stevia sebelum dan setelah proses adsorpsi (a)kuantitatif (b)kualitatif 
Tannin analysis with Folin-Denis at stevia leaf extract

Tannin concentration shows the greatest impact on taste and mouthfeel, significantly increasing sourness, bitterness, astringent texture, drying, and overall astringency (Frost et al., 2017). Polyphenols as tannin may contribute directly to plant-based foodstuffs flavor, particularly astringency and bitterness (Soares et al., 2020). For making a consumable stevia extract, this component must be eliminated.

Tannin content in stevia leaf extract before purification was $850 \mathrm{ppm}$. The tannin content in the extract makes the taste unpleasant, so that it reduces the desire to consume. Degradation of tannin can be seen in Figure 5 after the adsorption process carried out with activated and natural bentonite. Tannin levels in the solution after applying natural Na-bentonite decreased compared to the initial solution, but the levels were still high. Along with the decrease in tannins, it is hoped that the unpleasant taste in the extract will disappear. The application of activated and natural $\mathrm{Ca}$ bentonite significantly reduced tannin levels up to $97 \%$. This research has a better result than Kusumaningsih et al. (2015) using activated charcoal only by $39.74 \%$.

\section{Stevioside content in stevia leaf extract}

Water is a safe solvent used to extract stevia leaf for consumption. Besides, stevioside compounds, which are responsible for the sweet taste are more soluble in polar. Stevia extract in water has a dark green color that becomes brown due to the browning process caused by the heating during the extraction process. The main advantage of stevioside over other compounds in stevia extract is stable at $100^{\circ} \mathrm{C}$ (Buckenhuskers \& Omran, 1997). The extract has about 6-10\% stevioside content with up to 200 times the sweetness of glucose (Shamima et al., 2019). The results of the analysis of stevioside levels in the extract used can be seen in Figure 6.

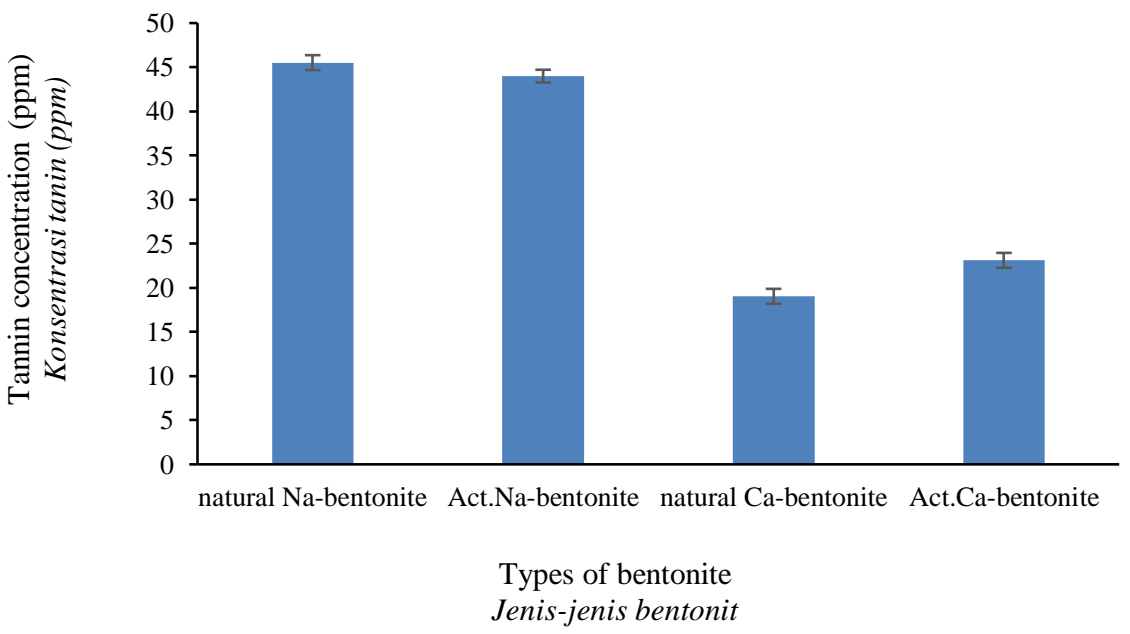

Figure 5. Tanin concentration after purification Gambar 5. Konsentrasi tannin setelah pemurnian

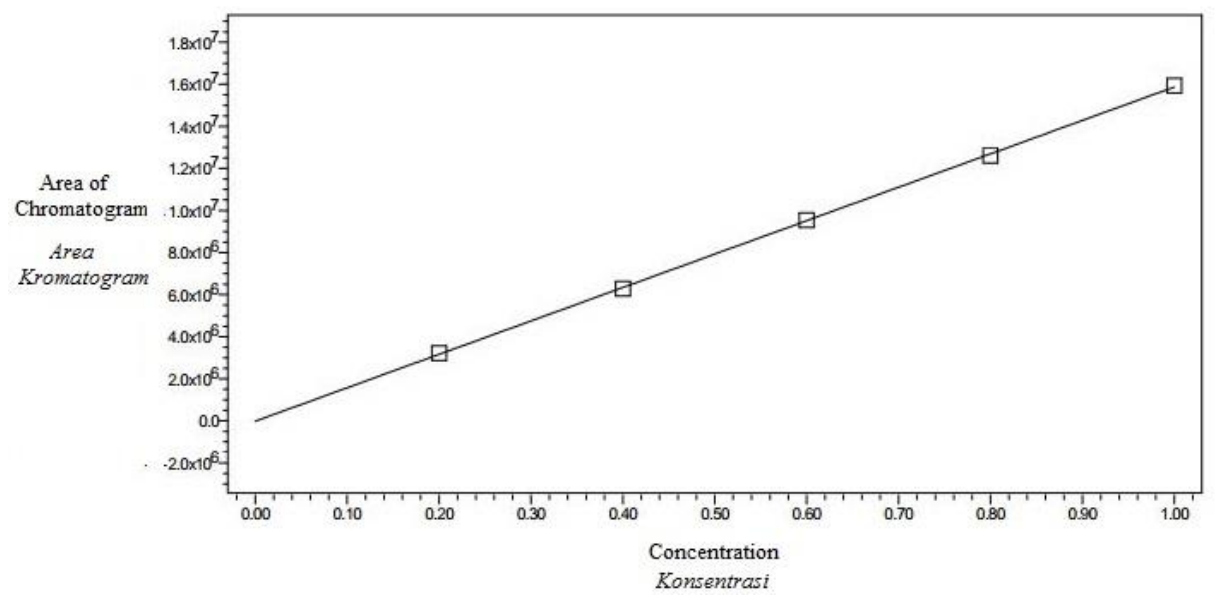

Figure 6. Standard series of stevioside Gambar 6. Deret standar steviosida 
The more water used for extraction, the more stevioside is extracted from stevia leaves, but the concentration of stevioside in the extract decreased (Refai et al., 2020). Pigments present in the crude extract affected the purification process and affected the purity of the produced stevioside. Moreover, de-pigmentation as indication on the removal of pigments (carotenoids and chlorophylls $a$ and $b$ ) were increased during this process. This means at the same time that the natural stevioside sweetener was extracted from the dried ground leaves by water was rich in pigments. These results are in line with those mentioned by Abdel-salam $e t$ al. (2009).

Before injecting the sample, verification of the modified method used had been carried out. A series of stevioside standard was analyzed at 200 , 400, 600, 800, and $1000 \mathrm{ppm}$. Then the correlation between concentration and area read from HPLC is depicted in graphical form, which can be seen in Figure 6. The linearity of the curve is then determined and produces the equation of $y=1.59 e^{7} x-1.54 e^{4}$ with $\mathrm{R}^{2}$ 0.999798. By using this linear equation, $x$ (concentration) of stevioside in the solution can be calculated.

Quantitative calculation of stevioside using linier equation from standard series mentioned before. Steviosides in stevia leaves have varying levels based on the extraction technique and solvent used (Kartikasari et al. 2018; Wuryanto \& Wahono, 2014). In this research, the crude extract having a stevioside concentration of $10.04 \pm$ $0.26 \mathrm{~g} / 100 \mathrm{~mL}$. From Figure 7, Ca bentonite resulting a slightly similar concentration of stevioside after the adsorption process between crude extract, natural and activated bentonite. Meanwhile, Na bentonite shows a different level of stevioside resulted from the adsorption process, which produce the lowest concentration at adsorption with natural $\mathrm{Na}$ bentonite. Stevioside level after treatment with activated $\mathrm{Na}$ bentonite is $1.02 \pm 0.37 \mathrm{~g} / 100 \mathrm{~mL}$ extract. At the same condition, $\mathrm{Ca}$ bentonite adsorption for the stevia extract resulting the stevioside level at $4.19 \pm$ $0.88 \mathrm{~g} / 100 \mathrm{~mL}$. Activated Ca bentonite can make a recovery level at as much as $41.75 \%$ of stevioside from the crude extract.

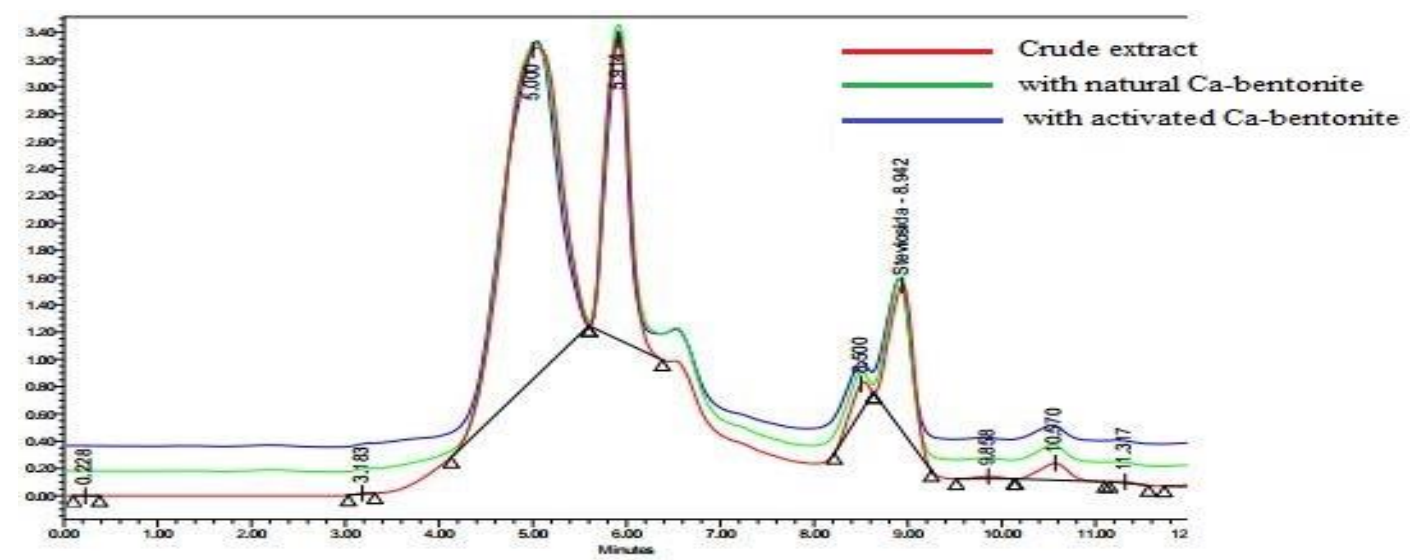

(a)

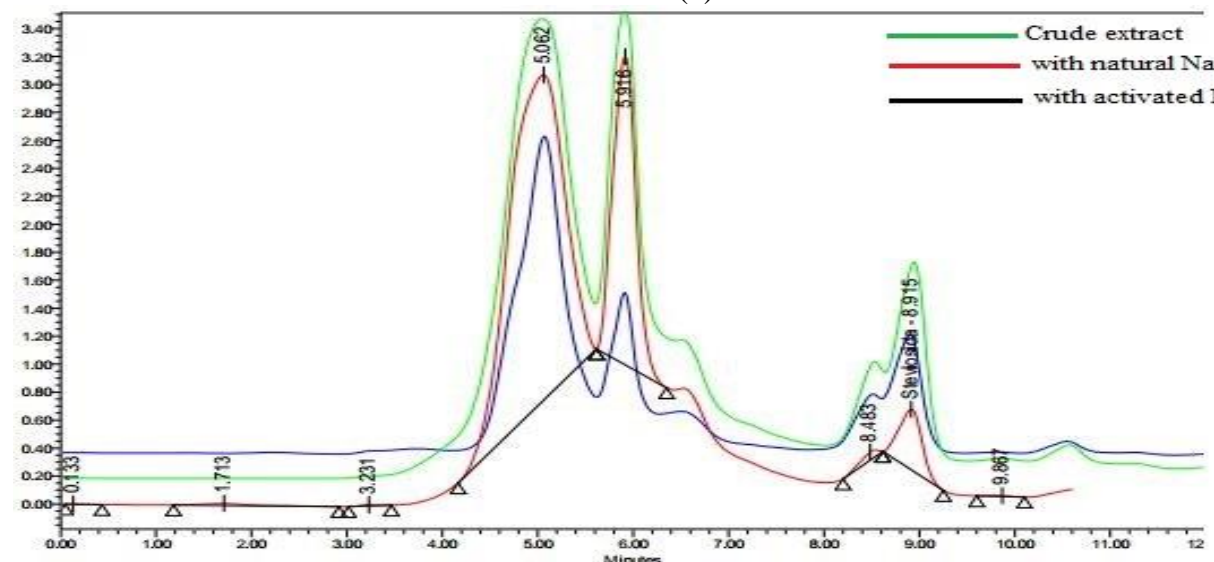

(b)

Figure 7. HPLC for stevia extract (a) using Ca-bentonite (b) using Na-bentonite Gambar 7. KCKT untuk ekstrak stevia (a) dengan Ca-bentonit (b) dengan Na-bentonit 


\section{Conclusion}

The best optimization conditions for the activation process of $\mathrm{Na}$ bentonite were $0.17 \mathrm{~N}$ $\mathrm{H}_{2} \mathrm{SO}_{4}$ and $358^{\circ} \mathrm{C}$ furnace heat, while for $\mathrm{Ca}$ bentonite were $0.17 \mathrm{~N} \mathrm{H}_{2} \mathrm{SO}_{4}$ and heat of $481{ }^{\circ} \mathrm{C}$. The maximum adsorption capacities of bentonite $\mathrm{Na}$ and $\mathrm{Ca}$ were $197.72 \mathrm{mg} \mathrm{g}^{-1}$ methylene blue and $169.52 \mathrm{mg} \mathrm{g}^{-1}$ methylene blue, respectively. The adsorbent application to the crude extract of stevia leaves resulted in a promising purification step with an increase of $86.64 \%$ in clarity and an increase of $50.64 \%$ in recovery of stevioside content using activated Ca-bentonite.

\section{References}

Abdel-Salam AM, AS Ammar, \& WK Galal, (2009). Evaluation and properties of formulated low calories functional yoghurt cake. J Food Agric Environ 7(2), 218-221.

Arumsari K, A Siti \& N Nurrahman (2019). Kadar total fenol, aktivitas antioksidan, dan sifat sensoris teh celup campuran bunga kecombrang, daun mint dan daun stevia. $J$ Pangan dan Gizi 9(2), 79-93.

Benford DJ, M DiNovi \& J Schlatter (2007). Steviol Glycosides. USA. JECFA.

Buckenhuskers HJ \& HJ Omran (1997). Stevia rebaudiana Bertoni and stevioside. Sugar and $S$ Subst in food Proc Nutr 157-78.

Carakostas MC, LL Curry, AC Boileau \& DJ Brusick (2008). Overview: the history, technical function and safety of rebaudioside A, a naturally occurring steviol glycoside, for use in food and beverages. Food and Chem Toxicol 46(7), S1-S10.

Chaturvedula VSP \& I Prakash (2011). The aroma, taste, color and bioactive constituents of tea. $J$ Medicinal Plants Res 5(11), 2110-2124.

Chaturvedula VSP \& J Zamora (2014). ReversedPhase HPLC Analysis of Steviol Glycosides Isolated from Stevia rebaudiana Bertoni. Food and Nutrition Sci 5, 1711-1716.

de Paula Moraes É \& NRCF Machado (2001). Clarification of Stevia rebaudiana (Bert.) Bertoni extract by adsorption in modified zeolites. Acta Sci Maringá 23(6), 1375-1380.

Dewi TI \& M Twillana (2012). Bulk cooking oil quality improvement using adsorbent activated bentonite. Unesa J Chem, 1(2), 47-53.

Frost SC, JF Harbertson \& H Heymann (2017). A full factorial study on the effect of tannins, acidity, and ethanol on the temporal perception of taste and mouthfeel in red wine. Food Quality and Preference 62, 1-7.

Gasmalla MAA, R Yang \& X Hua (2015). Extraction of rebaudioside-A by sonication from Stevia rebaudiana Bertoni leaf and decolorization of the extract by polymers. $J$ Food Sci Technol 52(9), 5946-5953. doi:10.1007/s13197-015-1717-3

Husada VP, Y Martono \& CA Riyanto (2018). Optimasi waktu kontak adsorpsi ekstrak stevia (stevia rebaudiana bertoni) menggunakan adsorben macroporous yang teraktivasi asam. In:Prosiding Seminar Nasional Biologi dan Pendidikan Biologi, Salatiga, 28 Januari 2018, 152.

Kartikasari D, N Nurkhasanah, \& S Pramono (2018). Penetapan kadar steviosida pada simplisia dan ekstrak daun stevia rebaudiana dari tiga daerah berbeda. J Ilmu Farmasi dan Farmasi Klinik, 15(2), 18-23.

Kharismawati M, PI Utami, \& R Wahyuningrum (2009). Penetapan kadar tanin dalam infusa daun salam (Syzygium polyanthum (Wight.) Walp)) secara spektrofotometri sinar tampak. PHARMACY: J Farmasi Indonesia 6(01), 2227.

Kurniasari L, M Djaeni \& A Purbasari (2011). Aktivasi zeolit alam sebagai adsorben pada alat pengering bersuhu rendah. Reaktor 13(3), 178184.

Kusumaningsih T, NJ Asrilya, S Wulandari, DRT Wardan, K Fatikhin, (2015). Pengurangan Kadar Tanin pada Ekstrak Stevia Rebaudiana dengan Menggunakan Karbon Aktif. Alchemy J Penelitian Kimia 11(1), 81-89

Lemus-Mondaca R, A Vega-Gálvez, L Zura-Bravo \& K Ah-Hen (2012). Stevia rebaudiana Bertoni, source of a high-potency natural sweetener: A comprehensive review on the biochemical, nutritional and functional aspects. Food Chem 132(3), 1121-1132.

Liu Y, X Hua, M Wang \& R Yang (2019). Purification of the mother liquor sugar from industrial stevia production through one-step adsorption by non-polar macroporous resin. Food Chem 274, 337-344. doi:10.1016/j.foodchem.2018.08.130

Mahl CRA, SPD de Oliveira, BB da Silva, G da Igreja, MR Simões, \& CF da Silva (2010). Effect of ph on the clarification of stevia rebaudiana bertoni extract using alginate beads. Adsorption Sci Technol 28(2),189-194. doi:10.1260/0263-6174.28.2.189

Mahmudha S \& I Nugraha (2016). Pengaruh penggunaan bentonit teraktivasi asam sebagai katalis terhadap peningkatan kandungan senyawa isopulegol pada minyak sereh wangi kabupaten gayo lues-aceh. Chimica et Natura Acta 4(3), 123-129.

Martono Y \& KAKH Dewi (2013). Optimization of production process stevia beverages with 
antidiabetic activity. In Proc The 2nd International Conf the Indonesian Chem Soc 2013.

Mohammad RR, AM Othman \& AI Ina'am (2020). Activation of bentonite clay with $\mathrm{H} 2 \mathrm{SO} 4$ and study it's cation exchange capacity for methylene blue dye, $\mathrm{Co}$ (ii) and $\mathrm{Cr}$ (vi). In: The $6^{\text {th }}$ Periodical Sci Conf for Dams \& Water Resources Res Center. Iraq, 27-28 Oct 2008.

Noyan H, M Önal \& Y Sarıkaya (2008). A model developed for acid dissolution thermodynamics of a Turkish bentonite. $J$ Thermal Analysis and Calorimetry 94(2), 591-596.

Nunes CA \& MC Guerreiro (2011). Estimation of surface area and pore volume of activated carbons by methylene blue and iodine numbers. Química Nova 34(3), 472-476.

Raini M \& A Isnawati (2011). Kajian khasiat dan keamanan stevia sebagai pemanis pengganti gula, Media Litbang Kesehatan 21(4), 145-156

Ramadhani A, M Muhdarina \& A Linggawati (2015). Kapasitas adsorpsi metilen biru oleh lempung cengar teraktivasi asam sulfat. Jurnal Online Mahasiswa Fakultas Matematika dan Ilmu Pengetahuan Alam Universitas Riau 2(1), 232-238.

Raposo F, MA De La Rubia \& R Borja (2009). Methylene blue number as useful indicator to evaluate the adsorptive capacity of granular activated carbon in batch mode: Influence of adsorbate/adsorbent mass ratio and particle size. J Hazardous Materials 165(1-3), 291299.

Refai KM, MH Eweida, HE Ali \& MR Masoud (2020). Isolation and purification of stevioside from Stevia rebaudiana Shou2 variety. Environ Sci 15(3), 15-39.

Rožic L, T Novakovic \& S Petrovic (2010). Modeling and optimization process parameters of acid activation of bentonite by response surface methodology. Applied Clay Sci 48(12), 154-158.

Ruskandi C, A Siswanto \& R Widodo (2020). Karakterisasi fisik dan kimiawi bentonite untuk membedakan natural sodium bentonite dengan sodium bentonite hasil aktivasi. Jurnal Polimesin 18(1), 53-60.

Shamima KAA, MA Hoque \& MN Islam (2019). Isolation of Stevioside and related compounds from two types of Stevia rebaudiana (Bertoni) species from Bangladesh. International J Chem Mathematics and Physics 3, 95-99.

Soares SE, C Brandão, S Guerreiro, N Soares, V Mateus de Freitas (2020). Tannins in food: Insights into the molecular perception of astringency and bitter taste. Molecules 25(11), $2590,1-26$.

Tiwari S (2010). Stevia rebaudiana: a medicinal and nutraceutical plant and sweet gold for diabetic patients. International J Pharmacy and Life Sci 1(8), 451-457.

Wuryanto H \& HS Wahono (2014). Penyusunan standard operating procedures industri rumah tangga pangan pemanis alami instan sari stevia (Stevia rebaudiana). J Pangan dan Agroindustri 2(3), 76-87.

Yildiz N, Z Aktas \& A Calimli (2004). Sulphuric acid activation of a calcium bentonite, Particulate Sci Technol 22(1), 21-33, DOI: 10.1080/02726350490422392 